University of Nebraska - Lincoln

DigitalCommons@University of Nebraska - Lincoln

2019

\title{
Size Estimation of Pre-Columbian Caribbean Fish
}

\author{
Sandrine Grouard \\ Muséum national d'Histoire naturelle, grouard@mnhn.fr \\ Sophia Perdikaris \\ University of Nebraska-Lincoln, sperdikaris2@unl.edu \\ Nídia Cristina Espíndola Rodrigues \\ Muséum national d'Histoire naturelle \\ Irvy R. Quitmyer \\ Florida Museum of Natural History
}

Follow this and additional works at: https://digitalcommons.unl.edu/global

Part of the Animal Studies Commons, Biological and Physical Anthropology Commons, Geography Commons, and the International and Area Studies Commons

Grouard, Sandrine; Perdikaris, Sophia; Espíndola Rodrigues, Nídia Cristina; and Quitmyer, Irvy R., "Size Estimation of Pre-Columbian Caribbean Fish" (2019). Global Studies Papers \& Publications. 24.

https://digitalcommons.unl.edu/global/24

This Article is brought to you for free and open access by the School of Global Integrative Studies at DigitalCommons@University of Nebraska - Lincoln. It has been accepted for inclusion in Global Studies Papers \& Publications by an authorized administrator of DigitalCommons@University of Nebraska - Lincoln. 
Published in International Journal of Osteoarchaeology (2019) 29: 452-468. doi: 10.1002/oa.2782

Copyright 2019, Wiley. Used by permission.

Special Issue Paper

\title{
Size Estimation of Pre-Columbian Caribbean Fish
}

\author{
Sandrine Grouard, Sophia Perdikaris, Nídia Cristina Espíndola Rodrigues, Irvy R. Quitmyer
}

\begin{abstract}
In this contribution, we present a methodological approach to the identification of pre-Columbian Caribbean fisheries and examine the interrelationships of exploitation according to size for eight fish families, in a diachronic perspective for the Lesser Antilles. Based on the principles of size and growth allometries, biometric repositories have been reconstructed for modern families that represent different ecological environments: Holocentridae, Serranidae, Carangidae, Lutjanidae, Haemulidae, Scaridae, Acanthuridae, and Scombridae. The measured fish bone elements were selected based on their robustness and potential for recovery at archaeological sites. This resulted in a sample size totaling 563 modern osteological specimens, which provided reconstructed standard, fork, total lengths (SL, FL, TL), and body mass (BM) of fish. The calculations were based on 21,437 measurements and 5,889 log-linear and exponential equations. These formed the comparative baseline for the archaeoichthyofaunal bone samples. The zooarchaeological ichthyofauna studied by Funding information the authors derive from 142 assemblages and 11 major islands following the eastern Fondation Fyssen; ATM Biodiversité of MNHN and western arcs of the Lesser Antilles: Saint-Martin, Barbuda, Antigua (including Long Island), Guadeloupe (Grande-Terre, Basse-Terre, Les Saintes, Islets from Cul-de-Sac-Marin, la Désirade, Petite Terre, and Marie-Galante), and Martinique. Previous zooarchaeological analyses by the same authors identified 1,050,649 specimens of which 397,803 were fish. Among them, the skeletal remains of Holocentridae, Serranidae, Carangidae, Lutjanidae, Haemulidae, Scaridae, Acanthuridae, and Scombridae bones were measured, and biometric constants were applied. During the pre-Columbian period in the Caribbean, the length distribution curves possibly represent anthropogenic selections that follow statistical normal, Poisson, or bimodal distributions. Coral reef fish became increasingly important in subsistence, but fish sizes from all ecosystems decreased over time. From the estimates of zooarchaeological fish size and the ethnoarchaeological, historical, ethnographical, and biological sources, it was possible to infer the various strategies and equipment used by the Amerindian fishermen. It is likely that the same triad of practices (hooks/lines, nets, and traps) survived the passage of time and emerged to be among the most popular fishing techniques used by modern fishermen in the Lesser Antilles.
\end{abstract}

\section{Keywords}

Biometrics, Lesser Antilles, Pre-Columbian, Fish size, Palaeofishery, Zooarchaeology, Archaeoichthyology

\section{Introduction}

The subsistence quest of pre-Columbian Antillean populations is fundamentally linked to island environmental biodiversity and marine resources (Wing and Wing, 1995, 2001). Each settlement features unique choices that are a result of local availability and biodiversity. In other words, the archaeofauna recovered provides a baseline (Pauly, 1995) of specific patterns for marine species targeted in each time period of settlement (Grouard, 2010). Thus, the analysis of subsistence behaviors, food econo-
Grouard, Espindola Rodrigues: Muséum national d'Histoire naturelle, Paris, France

Perdikaris: University of Nebraska-Lincoln, Lincoln, Nebraska, USA Quitmyer: Florida Museum of Natural History, University of Florida, Gainesville, Florida, USA

Correspondence to Grouard, grouard@mnhn.fr (ORCID 000000022101-0879)

Received Nov 9, 2018; revised Mar 8, 2019; accepted May 7, 2019 
mics, fishing, hunting, and gathering are powerful indicators of the region-specific evolution of social structures and cultural relationships. Mauss (1923-1924) defined food as a social construct. Fishing practices contribute to this cultural definition as they are linked to nautical proficiency, fisheries expertise, knowledge of the sea and fish behavior, spatial organization of the sea bottom, and vernacular taxonomy of the selected species. They are also linked to economic choices of risk-taking versus working time and to age and gender group task sharing organization in a specific society (Grouard, 2001a). These parameters are often evaluated through the analysis of material culture, but only a few fishing artefacts (e.g. hooks and net weights) have been recovered from archaeological sites in the West Indies. The reconstruction of zooarchaeological fish size from bone measurements provides another indicator of technology as it directly correlates with standard length (SL) and body mass (BM) parameters of the fish and the environment to which they live in. Each habitat requires different forms of exploitation techniques. Many tropical fish spend time as juveniles in a mangrove environment before migrating during adulthood to another ecosystem such as a coral reef. The fishing technology (e.g. nets, traps, hook/line, spear, bow, and harpoons) used in each of these environments is therefore very distinct and hence size selective. Due to size, behavior, or abundance, some fish cohorts may be present in the environment but not accessible via some fishing techniques.

In this research, we apply the concepts of allometry to calculate fish body size (Reitz et al., 1987), SL (mm) and BM (g) of pre-Columbian zooarchaeological assemblages spanning 5,000 years in the Lesser Antilles. In so doing, we examine technological changes, procurement strategies and the habitats targeted by these people. The data also address the need to understand changing fish SL and BM baselines (Pauly, 1995; Pauly, Christensen, Dalsgaard, Froese, and Torres, 1998) that have been reported in previous research from island communities (Grouard et al., 2017; Perdikaris, 1999; Quitmyer et al., 2013; Wing and Wing, 1995, 2001). Zooarchaeological fish body size, SL and BM, were estimated through the use of log-linear regression constants (Peters, 1983). Allometry has the advantage of being biologically based and facilitates estimation of the biometrics of an organism through ontogeny (Peters, 1983; Reitz et al., 1987; Schmidt-Nielsen, 1984). A large comparative osteological collection of modern fish taxa of known size and weight representing each of the eight families, Holocentridae, Serranidae, Carangidae, Lutjanidae, Haemulidae, Scaridae, Acanthuridae, and Scombridae, was measured and allometrically correlated with zooarchaeological specimens to estimate SL and BM (Gould, 1966: 587; Gould, 1971; Huxley, 1932; Peters, 1983; Reitz et al., 1987). These data help in interpreting past harvest techniques and occasionally even the season of capture. Modern reference collections and environmental setting

Calculating fish body size is key to understanding the ecology and ecosystems of where the fish originated.
Many coral reef fish exhibit habitat partitioning throughout ontogeny. For example, schools of juvenile grunts (Haemulidae) early in their life cycles grow in the mangroves and seagrass beds, whereas the adults are found on coral reefs (Kimirei et al., 2013; Nagelkerken et al., 2000). Thus, the sizes of many tropical fish taxa are highly correlated with ontogenetic age and growth maturity and thus, their ecosystemic location.

Zooarchaeological studies in the West Indies (Bain et al., 2017; Giovas, 2016; Grouard, 2001a, 2010; MacArthur and Wilson, 1967; Perdikaris et al., 2017; Serrand, 2007; Wing and Wing, 2001) have demonstrated the long-term productivity of the island ecosystems, identifying a high diversity of marine taxa, which is still present today.

The Lesser Antilles form a double arch of Cenozoic islands over almost $850 \mathrm{~km}$ (Figure S1): the external one was formed during the Miocene and is characterized by calcareous islands and islets, and the inner (western) arc is made up of still active volcanic islands. These two arcs present two very different environments. The volcanic islands are mountainous with rainforests and rivers, surrounded by deep sea waters, and rocky reefs. On the other hand, the calcareous Miocene islands are covered by xerophytic forests with rolling hills, mangroves, lagoons, and extended coral reefs.

Four main ecosystems characterize the Lesser Antilles: coral reefs, mangroves, seagrasses, and deep offshore waters (Bouchon, Bouchon-Navarro, and Louis, 2002). Coral reefs, which protect the coastline from swells, represent an extremely rich and intricate ecosystem, harboring a great diversity of animal species and enabling the development of mangroves and seagrasses in bays and lagoons. Marine phanerogam meadows (seagrasses) are at the interface between coral reefs and mangroves. The deep offshore waters have poor productivity of phytoplankton and zooplankton; thus, this oligotrophic zone contains only few pelagic fish taxa. Extant pelagic fish, such as tuna, are only opportunistically harvested by local fishermen, but the zone supports a modern recreational fishery (Blanchet et al., 2002, p. 17).

Recent studies of marine biodiversity in the French West Indies have recorded 14 species of marine mammals, five species of sea turtles, more than 40 species of decapod crustaceans, 360 species of marine mollusks, and 40 species of echinoderms. Among the fishes, more than 300 species have been recorded along the coasts of the French West Indies. Within this region, about 220 species inhabit coral reefs, 87 species are in mangrove habitats, and 65 over seagrass bed bottoms (Bouchon et al., 2002; Pointier and Lamy, 1998).

Regarding the availability of fish families present on the Caribbean coasts, the most important ones for human consumption are, in terms of the number of species: Serranidae (34 spp.), Haemulidae (19 spp.), Carangidae (15 spp.), Scaridae (14 spp.), Lutjanidae (14 spp.), Labridae (10 spp.), Scombridae (10 spp.), Pomacentridae (9 spp.), and Holocentridae (7 spp.; see Page et al., 2013 for common and scientific names of fishes). These families 
correspond to more than half of the modern inventories (Blanchet et al., 2002; Bouchon et al., 2002; Carpenter, 2002; Froese and Pauly, 2018; Nagelkerken et al., 2000; Rousseau, 2010). The Acanthuridae have a small number of species $(n=3)$ but are numerically abundant. The Labridae and Pomacentridae specimens were not statistically viable in the modern osteological collections, so these two taxa were excluded. The eight families selected in this study represent 563 modern osteological specimens (Table 1).

\section{Archaeological collections and historical setting}

The Lesser Antilles have yielded many well-preserved and well-stratified archaeological sites that have been extensively excavated. The first recorded human settlement dates to around 3,500 years BCE on the Mesoindian (Archaic Age) site of Etang Rouge on Saint-Martin (Bonnissent et al., 2018). By 500 BCE, new migrations of farmer-potters from the Orinoco Basin in Venezuela (Keegan, 2000) had colonized the entire archipelago of the Lesser Antilles (Early Neoindian, Early Ceramic Age, Saladoid Cultures). Around AD 900, new cultures emerged and settled in various areas of the region (Late Neoindian, Late Ceramic Age, and Troumassoid Cultures) (Hofman and Hoogland, 2004). These people were hunter-gatherer-fishers and horticulturalists. Since 1492, European Plantation economies dominated the region and changed both nature and culture on the islands.

The zooarchaeological materials forming the core of this analysis are listed in Table 2 with the locations shown on the map in Figure S1. They represent 142 assemblages, mostly village refuse middens and, to a lesser extent, natural cave deposits and shell middens. The sampling methods were the same on each site (all the features and square meters divided by stratigraphic cultural layer were water sieved through a $2-\mathrm{mm}$ screen). The number of archaeological specimens recovered $(1,050,649)$ and the number of different assemblages (142) circumvent preservation bias. The samples were excavated from 11 islands: Saint-Martin, Barbuda, Antigua, Long Island, Guadeloupe (Grande-Terre, Basse-Terre, Les Saintes, Islets from Grand and Petit-Cul-de-Sac-Marin and PetiteTerre, La Désirade, Marie-Galante), and La Martinique. The earliest faunal assemblages were recovered from 12 pre-Amerindian Holocene deposits, eight Archaic, 11 Early Ceramic A, 13 Early Ceramic B, 31 Late Ceramic A, 18 Late Ceramic B, along with 49 Colonial period assemblages $\left(17^{\text {th }}-19^{\text {th }}\right.$ centuries AD). All the archaeological collections are new datasets, and the analyses were all carried out by the authors of the study.

\section{Methods}

The identification and analysis of the modern and zooarchaeological assemblages were made by one of us (SG) using the reference collections of the Muséum national d'Histoire naturelle Zooarchaeology Laboratory (MNHN-AASPE) in Paris, France, the University of Ne-
braska-Lincoln Zooarchaeology Laboratory (UNL) in Lincoln, Nebraska, USA (previously at Brooklyn College, CUNY), and the Environmental Archaeology Laboratory, Florida Museum of Natural History (FLMNH), University of Florida in Gainesville, Florida, USA.

The MNHN-AASPE Laboratory houses a large vertebrate and invertebrate osteological and zooarchaeological collection from the Caribbean (758 specimens and 346 taxa), providing a solid comparative collection for the identification of the zooarchaeological specimens. The UNL Zooarchaeology Laboratory curates 650 specimens representing 325 taxa. Some of the rarer zooarchaeological remains were identified at the FLMNH. The FLMNH osteological comparative collection is among the largest in the world, covering the individual variability known to exist in various taxa: nearly 12,000 individual vertebrate and invertebrate specimens accompanied by weights and measures are housed there. The identification of fish remains to species can often prove difficult, especially with closely related tropical taxa. The identifications were facilitated by the use of these extensive comparative collections, along with illustrations of skeletal elements of 100 common fish in the Lesser Antilles and a table key with the criteria for morphological recognition of skeletal parts of 44 fish taxa (Grouard, 2001a, Vol. II Annexes 8 and 9).

The zooarchaeological remains were recovered from water-sieved soil samples using 1- and 2.7-mm screens from all sealed contexts, allowing for the recovery of small body faunal remains (e.g. fish, amphibians, squamates, birds, and small mammals). Samples from the middens were collected volumetrically: A minimum of 1 $\mathrm{m}^{2}$ per unit for each cultural layer, plus $100 \%$ of the features and structures. The screen residue from each sample was sorted using a binocular microscope, either in the field laboratory or in the MNHN or CUNY laboratories. The use of this screening protocol enables all zooarchaeological remains, large and small, an equal chance of being recovered (Brinkhuizen and Clason, 1986; Casteel, 1974, 1976; Clason and Prummel, 1977; Payne, 1975; Quitmyer, 2004).

The sizes of the zooarchaeological fishes illustrate both the different ecosystems where the animals were probably caught, as well as the techniques used to catch them. It also provides information on age, trophic level, and can also identify possible anthropogenic or environmentally caused shifts in the population dynamics of reef, riverine, or mangrove taxa (Grouard, 2001b; Reitz and Wing, 1999; Schmidt-Nielsen, 1984; Wheeler and Jones, 1989; Wing and Wing, 2001).

As dimensions of fish bones correlate well with live body size and weight (allometric size and growth are close to isometric distribution), there are many ways of estimating body size, live BM (grams) or SL (mm), based upon different measurements of fresh fish skeletal parts (Casteel, 1974, 1976; Desse et al., 1987, 1989; Leach and Boocock, 1993; Leach et al., 1996a; Leach et al., 1996b; Wheeler and Jones, 1989). For some Caribbean 
Table 1. MNI, Number of Measurements, and Number of Equations by Family

\begin{tabular}{|c|c|c|c|}
\hline Family & MNI & Number of measurements & Number of equations (SL, TL, and mass) \\
\hline Holocentridae & 44 & 1,729 & 525 \\
\hline Holocentrus & 29 & 1,174 & \\
\hline Holocentrus adscensionis & 10 & 398 & \\
\hline Holocentrus rufus & 19 & 776 & \\
\hline Myripristis & 9 & 314 & \\
\hline Plectrypops & 1 & 40 & \\
\hline Neoniphon & 1 & 40 & \\
\hline Sargocentron & 4 & 161 & \\
\hline Serranidae & 135 & 4,656 & 1,056 \\
\hline Serraninae & 54 & 1,799 & \\
\hline Serranus & 3 & 73 & \\
\hline Centropristis & 12 & 401 & \\
\hline Diplectrum & 25 & 837 & \\
\hline Diplectrum formosum & 20 & 654 & \\
\hline Hypoplectrus & 8 & 262 & \\
\hline Paralabrax & 6 & 192 & \\
\hline Grammistinae (Rypticus) & 3 & 103 & \\
\hline Epinephelinae & 78 & 2,754 & \\
\hline Alphestes afer & 1 & 117 & \\
\hline Epinephelus & 36 & 1,241 & \\
\hline Epinephelus guttatus & 15 & 536 & \\
\hline Mycteroperca & 10 & 362 & \\
\hline Cephalopholis & 31 & 1,115 & \\
\hline Cephalopholis fulva & 20 & 732 & \\
\hline Carangidae & 93 & 3,133 & 825 \\
\hline Alectis ciliaris & 1 & 32 & \\
\hline Carangoides & 8 & 256 & \\
\hline Caranx & 30 & 1,065 & \\
\hline Caranx hippos & 17 & 640 & \\
\hline Caranx ruber & 8 & 256 & \\
\hline Chloroscombrus & 8 & 266 & \\
\hline Decapterus & 3 & 96 & \\
\hline Hemicaranx & 2 & 62 & \\
\hline Oligoplites & 5 & 149 & \\
\hline Selene & 17 & 580 & \\
\hline Seriola & 6 & 193 & \\
\hline Trachinotus & 8 & 267 & \\
\hline Trachurus & 13 & 423 & \\
\hline Lutjanidae & 76 & 2,183 & 453 \\
\hline Lutjanus & 61 & 1,837 & \\
\hline Lutjanus apodus & 7 & 209 & \\
\hline Lutjanus buccanella & 13 & 421 & \\
\hline Lutjanus campechanus & 17 & 499 & \\
\hline Etelis & 62 & 453 & \\
\hline Ocyurus & 6 & 158 & \\
\hline Pristipomoides & 1 & 4 & \\
\hline Rhomboplites & 6 & 122 & \\
\hline Haemulidae & 95 & 3,305 & 717 \\
\hline Anisotremus & 8 & 278 & \\
\hline Conodon & 7 & 241 & \\
\hline Haemulon & 66 & 2,306 & \\
\hline Haemulon plumieri & 30 & 1,044 & \\
\hline Haemulon flavolineatum & 8 & 281 & \\
\hline Orthopristis & 7 & 421 & \\
\hline Pomadasys & 1 & 35 & \\
\hline Xenichthys & 3 & 101 & \\
\hline Isacia & 3 & 103 & \\
\hline Scaridae & 50 & 2,121 & 666 \\
\hline Sparisoma & 46 & 1,984 & \\
\hline Sparisoma chrysopterum & 16 & 694 & \\
\hline Sparisoma rubripinne & 8 & 338 & \\
\hline Sparisoma viride & 17 & 731 & \\
\hline Scarus & 4 & 137 & \\
\hline
\end{tabular}


Table 1. (Continued)

$\begin{array}{llll}\text { Family } & \text { MNI } & \text { Number of measurements } & \text { Number of equations (SL, TL, and mass) } \\ \text { Acanthuridae } & 30 & 2,688 & 1,173 \\ \text { Acanthurus } & 30 & 2,688 & \\ \text { Acanthurus bahianus } & 13 & 1,167 & \\ \text { Acanthurus chirurgus } & 6 & 502 & 474 \\ \text { Acanthurus coeruleus } & 11 & 1,019 & \\ \text { Scombridae } & 40 & 1,622 & \\ \text { Acanthocybium } & 1 & 39 & \\ \text { Auxis } & 2 & 80 & \\ \text { Euthynnus } & 15 & 635 & \\ \text { Katsuwonus } & 1 & 42 & \\ \text { Scomber } & 5 & 195 & 5,889 \\ \text { Scomberomorus } & 10 & 402 & \\ \text { Thunnus } & 6 & 229 & \\ \text { Total } & 563 & 21,437 & \end{array}$

taxa, body weights are estimated using the first vertebrae width or otolith length (Quitmyer et al., 1985; Reitz et al., 1987; Reitz and Cordier, 1983; Reitz and Wing, 1999). Correlations between the body weight or length and otolith length $(\mathrm{mm})$ or vertebral width $(\mathrm{mm})$ did not provide accurate estimates of weight for some taxa in this study (correlation coefficients $\left[r^{2}\right]$ were too weak). As a result, various regression constants were calculated for each skeletal part (cranial bones and vertebrae) of the most common taxa from the zooarchaeological samples. Grouard and colleagues (Espindola Rodrigues and Grouard, 2014; Grouard, 2001b; Grouard et al., 2017) have previously established regression relationships using modern specimens for the most common fish species, genera, and families in the Lesser Antilles (Holocentridae, Serranidae, Carangidae, Lutjanidae, Haemulidae, Scaridae, Acanthuridae, and Scombridae). The comparative specimens used in calculating the allometric constants associated with fish taxa living in the Greater and Lesser Antilles, and Florida are from the osteological collections of the "Antilles in ASSPE laboratory" and FLMNH.

Allometry (scaling) best describes the consequences of changes in body metrics through ontogeny and is characterized by a mathematical function: $y=a x^{b}$ (Huxley, 1932; Krebs, 1989; Peters, 1983; Schmidt-Nielsen, 1984).

The allometric formula is transformed using the common logarithm to produce a straight line-regression because ontogenetic growth is nonlinear (Peters, 1983).
The transformed formula is

$$
\log y=\mathrm{a}+\mathrm{b}(\log x), \text { where }
$$

$y$ the dependent variable, the predicted standard length or body mass

a empirically derived $y$-intercept

b empirically derived slope of the line

$x$ the independent variable (skeletal measurement of the zooarchaeological bone).

However, the standard error, the determination coefficient $\left(R^{2}\right)$ and the coefficient correlation $(r)$ of the exponential and the linear functions are similar in most cases. Consequently, the linear equations were chosen to be presented in the length estimates of the archaeozoological specimens (Tables S1 to S8).

Because the identification of fragmented archaeological bones is often difficult to differentiate at the species level, for the most common taxa of each family mentioned above, allometric constants were calculated at the level of species, genus, subfamily, and family, including measurements of the vertebrae and cranial bones (Figure 1 ). We only use those constants when the correlation is excellent (when the correlation coefficient $[r]$ is between .9 and 1 and the probability is less than .0001) as recommended by Desse and Desse-Berset (1996b); Grouard, 2001b; examples at the level of genus in Figure 2). Fish sizes for all zooarchaeological taxa were calculated using 
Table 2. Sites by Island, Number of Assemblages, Cultural Time Period, and NISP

\begin{tabular}{|c|c|c|c|c|c|c|c|c|c|}
\hline Islands & Sites & Holecene & $\begin{array}{l}\text { Ar- } \\
\text { chaic }\end{array}$ & $\begin{array}{l}\text { Early } \\
\text { Ceramic } \\
\text { A }\end{array}$ & $\begin{array}{l}\text { Early } \\
\text { Ceramic } \\
\text { B }\end{array}$ & $\begin{array}{l}\text { Late } \\
\text { Ceramic } \\
\text { A }\end{array}$ & $\begin{array}{l}\text { Late } \\
\text { Ceramic } \\
\text { B }\end{array}$ & $\begin{array}{l}\text { XVII- } \\
\text { XIX }\end{array}$ & $\begin{array}{l}\text { NISP } \\
\text { Total }\end{array}$ \\
\hline Saint-Martin & $\begin{array}{l}\text { Baie Orientale } \\
\text { Etang Rouge 04 } \\
\text { Lot } 73 \text { Baie Longue } \\
\text { Hope Estate } \\
\text { BK76-Grand Case } \\
\text { BK77-Route l'espérance } \\
\text { BK78-rue de la petite plage } \\
\text { Pointe du Canonnier } \\
\text { Baie aux Prunes } \\
\text { Habitation Mont Vernon }\end{array}$ & & $\begin{array}{l}X \\
X \\
X\end{array}$ & $\mathrm{X}$ & & $\begin{array}{l}X \\
X \\
X \\
X\end{array}$ & $\mathrm{X}$ & $\begin{array}{l}X \\
X \\
X \\
X \\
\\
X\end{array}$ & 86,023 \\
\hline Barbuda & $\begin{array}{l}\text { Barbuda Cave I } \\
\text { Barbuda Cave II } \\
\text { Barbuda Cave III } \\
\text { Barbuda Cave IV } \\
\text { Barbuda Cave V } \\
\text { Rat Poket } \\
\text { Two Foot Bay 1 } \\
\text { Burton's Field } 2012 \\
\text { Cattle Field } 2012 \\
\text { River site 2011 } \\
\text { Strombus line } \\
\text { Seaview } \\
\text { Sufferers } \\
\text { Indian Town Trail } \\
\text { Welches } \\
\text { Castle Bay Cave } \\
\text { Castle Hill Cave } 2008 \\
\text { Nicey Cave 2009 } \\
\text { Overview Cave } \\
\text { Two Foot Bay } 2 \\
\text { Two Foot Bav } 3\end{array}$ & $\begin{array}{l}X \\
X \\
X \\
X \\
X \\
X \\
X\end{array}$ & $\begin{array}{l}X \\
X \\
X \\
X\end{array}$ & $\mathrm{X}$ & $X$ & $\mathrm{X}$ & $\begin{array}{l}X \\
X\end{array}$ & $\begin{array}{l}X \\
X \\
X \\
X \\
X \\
X\end{array}$ & 7,965 \\
\hline Antigua & $\begin{array}{l}\text { Burma Quarry } \\
\text { Blackman's } \\
\text { Indian Creek } \\
\text { Muddy Bay } \\
\text { Mill Reef } \\
\text { Marmora Bay } \\
\text { Jumpy Bay } \\
\text { Sugar Mill }\end{array}$ & $\mathrm{X}$ & & & & $\begin{array}{l}X \\
X \\
X \\
X \\
X\end{array}$ & $\begin{array}{l}X \\
X\end{array}$ & $\mathrm{X}$ & 16,978 \\
\hline Basse Terre & $\begin{array}{l}\text { Cathédrale de Basse Terre } \\
\text { Gare Maritime } \\
\text { 24, rue Schoelcher } \\
\text { Place Saint François } \\
\text { Embouchure Rivière de Bailiff } \\
\text { Sainte Rose La Ramée } \\
\text { Pointe de Grande-Anse Trois } \\
\text { Rivières } \\
\text { Roseau Capesterre } \\
\text { Couvent des Capucins-EHPAD } \\
\text { Habitation Berg } \\
\text { Habitation de Sweers } \\
\text { Habitation Eveillard-Diavet } \\
\text { Habitation La Mahaudière } \\
\text { La Diotte }\end{array}$ & & & $\begin{array}{l}X \\
X \\
X \\
X\end{array}$ & $\begin{array}{l}X \\
X \\
X\end{array}$ & $\begin{array}{l}X \\
X\end{array}$ & $\begin{array}{l}X \\
X\end{array}$ & $\begin{array}{l}591 \\
\\
X \\
\\
X \\
X \\
X \\
X \\
X \\
X \\
X\end{array}$ & 88,188 \\
\hline $\begin{array}{l}\text { Grande } \\
\text { Terre }\end{array}$ & $\begin{array}{l}\text { Anse à l'Eau } \\
\text { Morel } \\
\text { Petites Salines } \\
\text { Anse à la Gourde } \\
\text { Grotte Papin } \\
\text { CHU Belle Plaine }\end{array}$ & & & $\begin{array}{l}X \\
X\end{array}$ & $\begin{array}{l}X \\
X\end{array}$ & $\begin{array}{l}X \\
X\end{array}$ & $\begin{array}{l}X \\
X\end{array}$ & $\begin{array}{l}X \\
X\end{array}$ & 232,835 \\
\hline
\end{tabular}

(Continues) 
Table 2. (Continued)

\begin{tabular}{|c|c|c|c|c|c|c|c|c|c|}
\hline Islands & Sites & Holocene & Archaic & $\begin{array}{l}\text { Early } \\
\text { Ceramic } \\
\text { A }\end{array}$ & $\begin{array}{l}\text { Early } \\
\text { Ceramic } \\
\text { B }\end{array}$ & $\begin{array}{l}\text { Late } \\
\text { Ceramic } \\
\text { A }\end{array}$ & $\begin{array}{l}\text { Late } \\
\text { Ceramic } \\
\text { B }\end{array}$ & $\begin{array}{l}\text { XVII } \\
-\mathrm{XIX}\end{array}$ & $\begin{array}{l}\text { NISP } \\
\text { Total }\end{array}$ \\
\hline & $\begin{array}{l}\text { Pointe du Helleux } \\
\text { Grotte de l'Anse à la Gourde } \\
\text { Grotte de l'Anse à l'Ecu } \\
\text { Habitation Laprade, Barbès } \\
\text { Habitation Macaille } \\
\text { Trou Lolo }\end{array}$ & & & & & & $X$ & $\begin{array}{l}\mathrm{X} \\
\mathrm{X} \\
\mathrm{X} \\
\mathrm{X} \\
\mathrm{X}\end{array}$ & \\
\hline Cul-de-Sac-Marin & $\begin{array}{l}\text { Ilet Colas } \\
\text { Ilet Chasse }\end{array}$ & & & & & & & $\begin{array}{l}X \\
X\end{array}$ & 198 \\
\hline La Désirade & $\begin{array}{l}\text { Les Sables } \\
\text { Pointe Gros Rempart Puits } 6 \\
\text { Petite Rivière } \\
\text { Aéroport } \\
\text { Grand Abaque } 1 \\
\text { Voûte à Pin } \\
\text { A l'Escalier } \\
\text { Mome Cybèle }\end{array}$ & & & & $\begin{array}{l}X \\
X\end{array}$ & $\begin{array}{l}\text { X } \\
\text { X } \\
\text { X } \\
\text { X }\end{array}$ & $\begin{array}{l}X \\
X\end{array}$ & $\begin{array}{l}X \\
X \\
X\end{array}$ & 53,393 \\
\hline Ilets de Petite Terre & $\begin{array}{l}\text { Baleine du Sud } \\
\text { Caille à Bélasse } \\
\text { Est de Mouton de Bas } \\
\text { Name Unknown } \\
\text { Pointe Sablé } \\
\text { Site du Phare }\end{array}$ & & & & & $\begin{array}{l}X \\
X \\
X \\
X \\
X \\
X\end{array}$ & & $\begin{array}{l}\text { X } \\
\text { X }\end{array}$ & 1,677 \\
\hline Marie-Galante & $\begin{array}{l}\text { Abri Cadet } 3 \\
\text { Grotte Cadet } 2 \\
\text { Grotte Blanchard } \\
\text { Grotte Blanchard } 2 \\
\text { Grotte du Morne Rita } \\
\text { Folle Anse } \\
\text { Stade José Bade } \\
\text { Tourlourous } \\
\text { Taliseronde } \\
\text { Fossé Petite Anse } \\
\text { Anse du Coq } \\
\text { Ravine }\end{array}$ & $\begin{array}{l}X \\
X \\
X \\
X\end{array}$ & $\mathrm{X}$ & $\begin{array}{l}X \\
X\end{array}$ & $\begin{array}{l}X \\
X \\
X\end{array}$ & $\begin{array}{l}\text { X } \\
X \\
X \\
X \\
X \\
X\end{array}$ & $\mathrm{X}$ & $\begin{array}{l}X \\
X \\
X \\
X \\
X \\
X \\
X \\
X \\
X\end{array}$ & 473,188 \\
\hline Les Saintes & $\begin{array}{l}\text { Grande Anse Terre de Bas } \\
\text { Ethnoarchéologie }\end{array}$ & & & & & & $\mathrm{X}$ & $\mathrm{X}$ & 49,704 \\
\hline La Martinique & $\begin{array}{l}\text { Clavius Marius } \\
\text { Salines } \\
\text { Dizac } \\
\text { Macabou } \\
\text { Paquemar } \\
\text { Anse Trabaud } \\
\text { Habitation Crève Cœur } \\
\text { Moulin Val d'Or }\end{array}$ & & & $\mathrm{X}$ & $\begin{array}{l}X \\
X \\
X\end{array}$ & $\mathrm{X}$ & $\begin{array}{l}X \\
X \\
X \\
X\end{array}$ & $\begin{array}{l}X \\
X \\
X \\
X \\
X \\
X\end{array}$ & 40,500 \\
\hline Total NISP & & 103,592 & 2,636 & 109,701 & 69,053 & 333,414 & 141,216 & 40,981 & $1,050,649$ \\
\hline Total N sites & & 12 & 8 & 11 & 13 & 31 & 18 & 49 & 142 \\
\hline
\end{tabular}

identifiable elements complete enough for precise measurement. Before choosing measurements for analysis, the random nature of the processes of destruction indicated by the distribution of body parts was verified for each sample, as suggested by Leach and Boocock (1995: 27). All linear measurements are in millimeters, and all weights are in grams. The total length (TL) or the BM could have been used to illustrate the archaeological estimations of fish sizes. However, in this study, we applied the SL because it seems to better correspond with the mesh size of the casts and nets. 


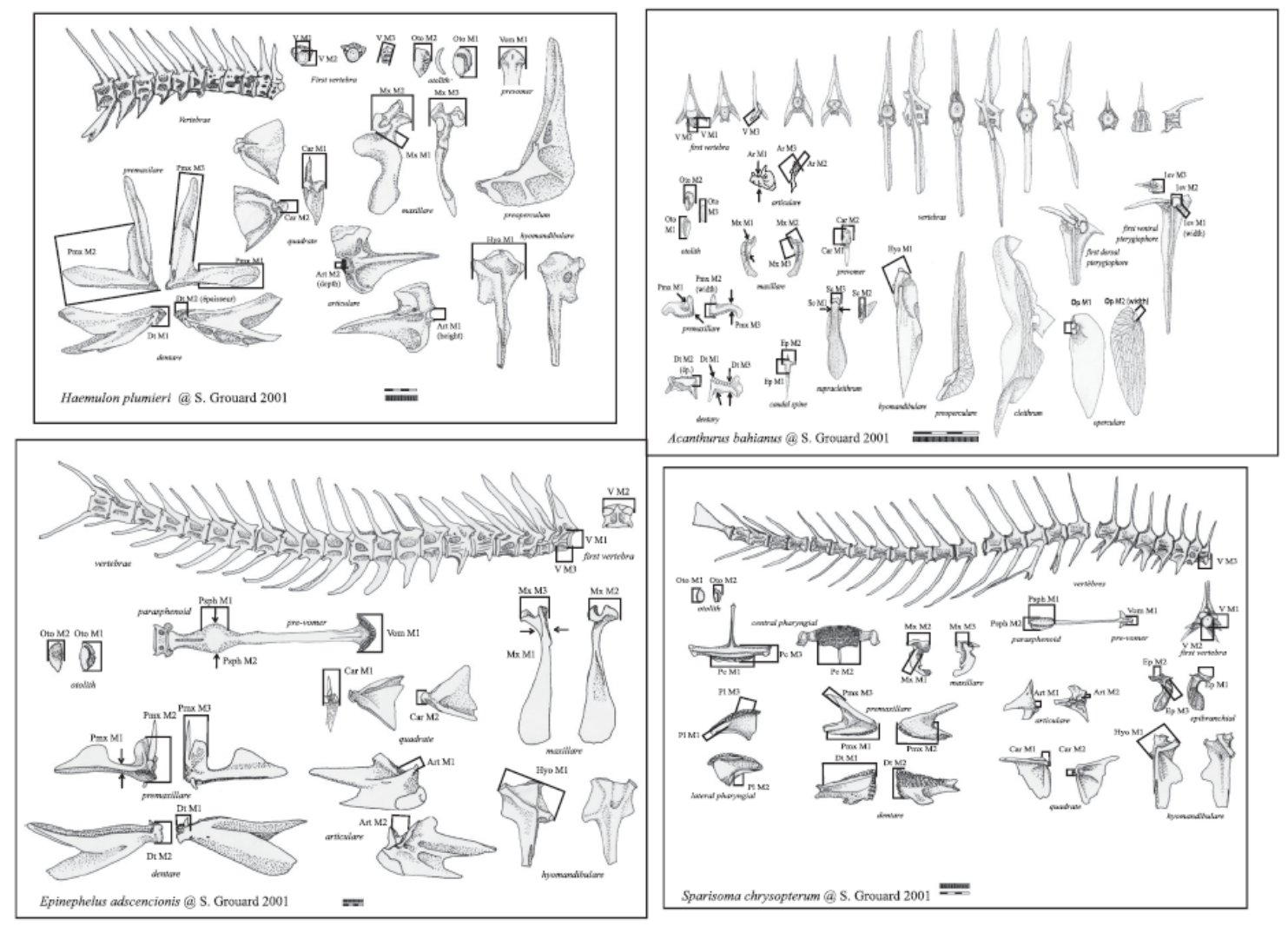

Figure 1. Osteometry of Haemulidae, Serrandiae, Acanthuridae, and Scaridae

\section{Results}

Modern comparative specimens: Fish size estimation equations

The 563 osteological specimens $(n)$ resulted in 21,437 measurements (m) and 5,889 equations for size estimations at the level of family (including different genera and several species), at the level of genera and at the level of species (Table 1; see also Table S1 Holocentridae, Table S2 Serranidae, Table S3 Carangidae, Table S4 Lutjanidae, Table S5 Haemulidae, Table S6 Scaridae, Table S7 Acanthuridae, and Table S8 Scombridae) of the SL (mm), TL (mm), and BM (g). We note that BM represents soft and supportive tissue.

We found that not all the measurements have a good correlation with body metrics, when the $\mathrm{r}$ coefficient is < .9 , and probabilities $.02>p>.01$, according to the df. In this case, our hypothesis Ho, which advocates the absence of correlation between the variables $\mathrm{X}$ (measurement of the skeletal part analyzed) and Y (SL), was rejected, but the equations were used with caution because the probability was slightly less significant. Only 25 of 5,889 equations $(.42 \%)$ had to be rejected because the correlation was not significant $(p>.2)$, and the size estimation of the zooarchaeological individuals cannot be used (see Tables S1-S8).
As highlighted elsewhere (Cooke and Jiménez, 2004; Jiménez-Cano and Masson, 2016; Lidour, Vorenger, and Béarez, 2018), working at the species level allows the finest application of ecological studies to document ancient fishing; however, the identification of fragmented archaeological bones is often difficult to differentiate at the species level. Consequently, allometric constants were calculated at the level of family, subfamily, genera, and species. Number is important for statistical significance, but body size ranges resulted in highly accurate data. The metrics could be a powerful specific identification tool. Indeed, the species or genera within a family can be determined using the measurements (e.g. the grunts, Haemulidae: Anisotremus spp. and Conodon spp., or jacks, Carangidae: Trachurus spp. and Trachinotus spp.).

Finally, > 97\% of the size estimation equations $(5,731 / 5,889)$ have a high correlation coefficient and a highly significant probability $(p<.01)$ at the level of species, genus, subfamily, and family. Consequently, these series of predictive equations are statistically useful to reconstruct the size of the zooarchaeological specimens but require staying within the range indicated by the two extreme size margins noted in the equation. Indeed, if a zooarchaeological fish were bigger or smaller than the sizes covered in the reference collection, size estimation would be hypothetical because of the lack of direct correlates. 


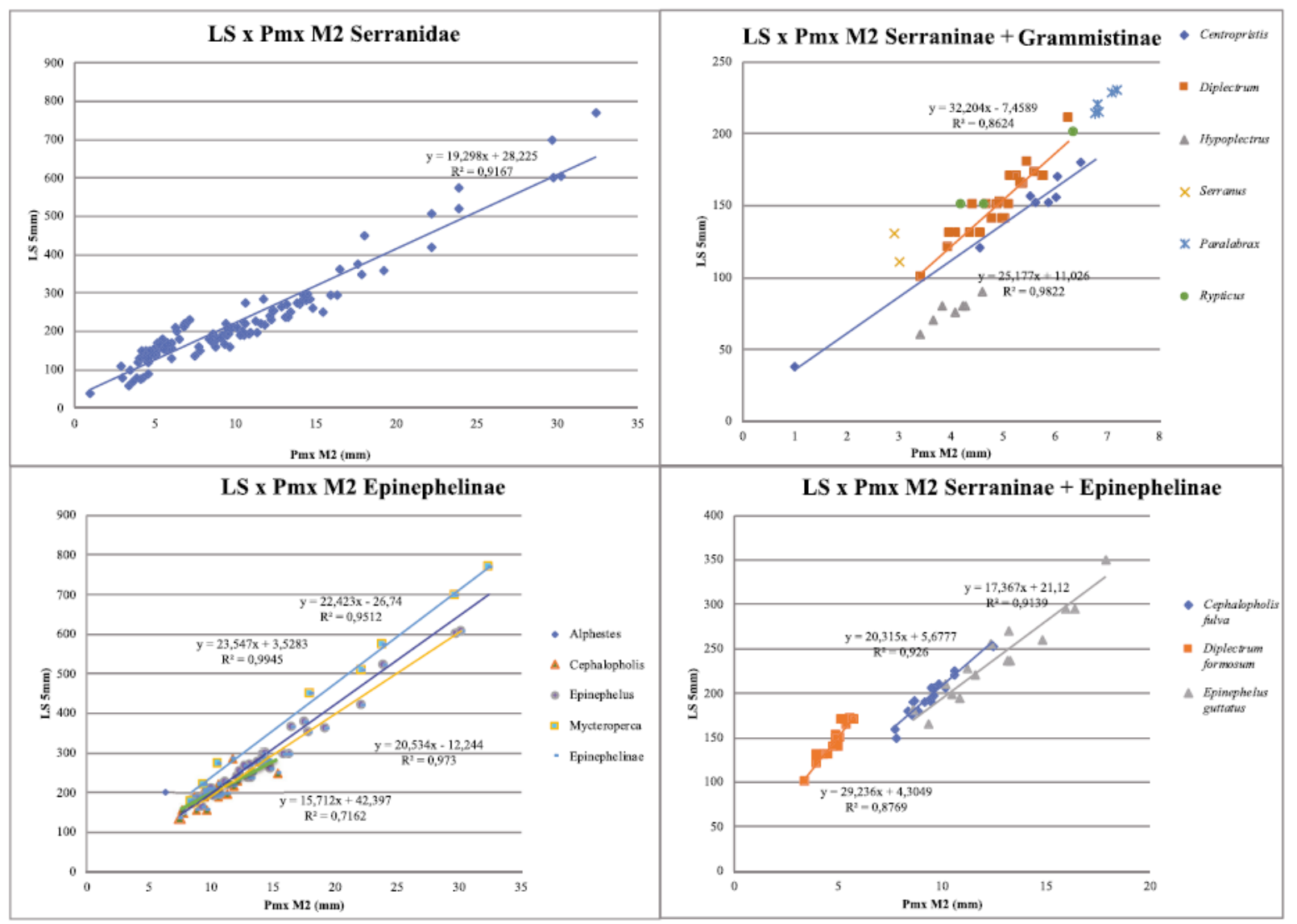

Figure 2. Examples of regression of the standard length based on the Measure 2 of premaxillary of Serranidae, Epinephelinae, Diplectrum sp., Centropristis sp., Cephalopholis sp., Epinephelus sp., Mycteroperca sp., Cephalopholis fulva, Diplectrum formosum, and Epinephelus guttatus [Color figure can be viewed at https://onlinelibrary.wiley.com]

\section{Zooarchaeological applications}

Zooarchaeological analysis of the 142 archaeological assemblages resulted in the identification of 1,050,649 specimens, of which 397,803 were fish (ray-finned fishes, Teleostei, and sharks/skates/ rays, Chondrichthyes), and 379,634 were terrestrial vertebrates (Lissamphibiansfrogs, Squamates-lizards and snakes, Testudines - tortoises and turtles, Aves - birds, and Mammalia - mammals). This resulted in a total of 46 fish families and 212 fish species within the vertebrate specimens (Table 3), with differences among the time periods: pre-Amerindian
Holocene (8/9), Archaic (6/17), Early Ceramic A (30/114), Early Ceramic B (35/119), Late Ceramic A (42/166), Late Ceramic B (35/118), and Colonial (32/84).

The sample sizes of the Archaic and pre-Amerindian Holocene assemblages are small, thus contributing to less taxonomic diversity (Figure 3), and cannot be confidently used to represent zooarchaeological diversity during those periods. Greater numbers of fish taxa were identified in the Late Ceramic Age A $(S=166)$, where there are also a greater number of sites $(n=42)$. The highest percentage of fish remains was found within the Late Ceramic Age B (86\%) deposits.

Table 3. NISP of Vertebrata, NISP of Fish, Number of Fish Families, and Number of Fish Taxa (S), Margaleff index dI $=(\mathrm{S}-1) / \operatorname{Logn}(\mathrm{N})$

\begin{tabular}{|c|c|c|c|c|c|c|c|c|}
\hline & Holocene & Archaic & $\begin{array}{l}\text { Early } \\
\text { Ceramic A }\end{array}$ & $\begin{array}{l}\text { Early } \\
\text { Ceramic B }\end{array}$ & $\begin{array}{l}\text { Late } \\
\text { Ceramic A }\end{array}$ & $\begin{array}{l}\text { Late } \\
\text { Ceramic B }\end{array}$ & $\begin{array}{l}\text { XVII- } \\
\text { XIX }\end{array}$ & Total assemblages \\
\hline Number of sites & 12 & 8 & 11 & 13 & 31 & 18 & 49 & 142 \\
\hline NISP total Vertebrata & 103,592 & 2,636 & 109,701 & 69,053 & 333,414 & 141,216 & 40,981 & $1,050,649$ \\
\hline NISP fish & 210 & 148 & 38,498 & 52,233 & 182,832 & 121,649 & 2,233 & 397,803 \\
\hline $\mathrm{S}$ fish families & 8 & 6 & 30 & 35 & 42 & 35 & 32 & 46 \\
\hline S fish taxa & 9 & 17 & 114 & 119 & 166 & 118 & 84 & 212 \\
\hline$\%$ Fish & $0 \%$ & $6 \%$ & $35 \%$ & $76 \%$ & $55 \%$ & $86 \%$ & $5 \%$ & $38 \%$ \\
\hline D1 Fish & 1.5 & 3.2 & 10.7 & 10.9 & 13.6 & 10.0 & 10.8 & 16.4 \\
\hline
\end{tabular}




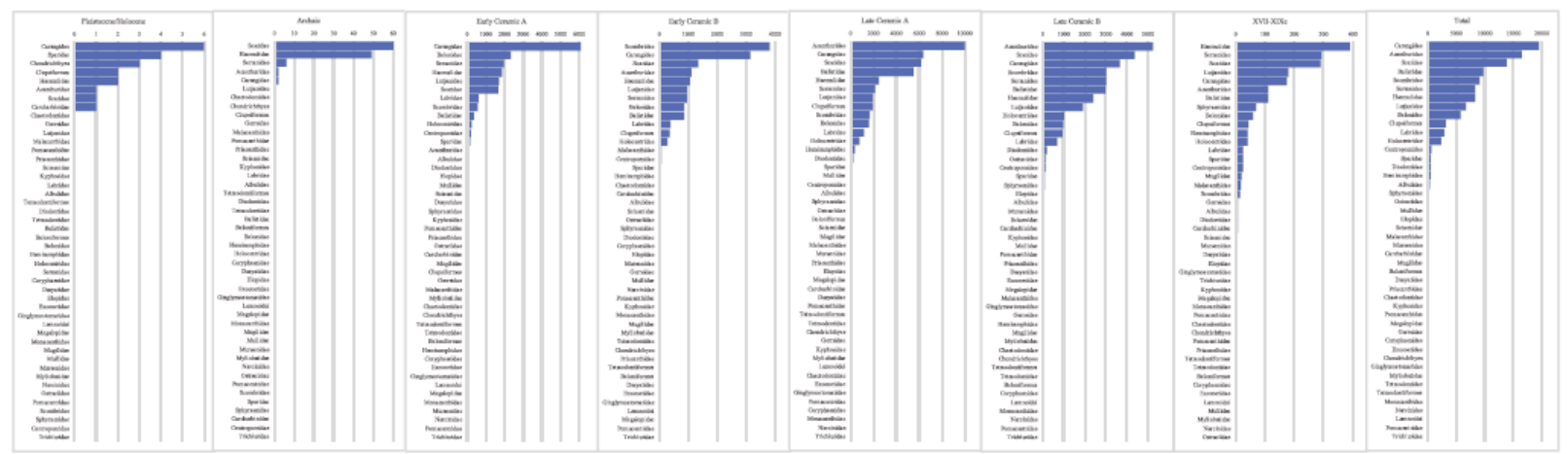

Figure 3. Identified fish families by archaeological period ordered by contribution to assemblage (NISP) [Color figure can be viewed at https://onlinelibrary.wiley.com]

\section{Estimation of fish size}

For the entire assemblage (21,265 measured fish), the estimations of the fish populations have a mean SL of $293.1 \mathrm{~mm}$ (Figure 4 and Table 4 ) and range between 22.8 $\mathrm{mm}$ SL and $3041.1 \mathrm{~mm}$ SL.

Figure 4 shows the size histogram for the eight families during all periods. We can see at least a bimodal curve. The distribution is a double curve with a large distribution weighted to the left of the mean, suggesting that many of the fish are smaller than the median (between 100 and $300 \mathrm{~mm}$ ), but a second distribution is present, with large specimens between 450 and $800 \mathrm{~mm}$. The smaller fish include mostly juvenile Lutjanidae, Haemulidae, Acanthuridae, Holocentridae, and Scaridae. The larger individuals are mostly Scombridae, Carangidae, Serranidae, Scaridae, and Lutjanidae and likely represent pelagic schools or solitary adult carnivorous fish feeding on the reef and inshore fish.

According to the Agostino test (Chenorkian, 1996), none of the size class distributions of any family but Scombridae follow a normal distribution (Figure 5 and Table 4). Indeed, each fish family has their its [sic], but three kinds of distributions appear: The Acanthuridae, Haemulidae, and Holocentridae are very close to each other; the Lutjanidae and Scaridae have the same kind of distribution; and the Scombridae, Serranidae, and Carangidae have bimodal curves.

Within the Holocentridae ( $\min 89 \mathrm{~mm}$, $\max 403 \mathrm{~mm}$, mean $189 \mathrm{~mm}$ ), the Acanthuridae ( $\min 60 \mathrm{~mm}$, max 456 $\mathrm{mm}$, mean $161 \mathrm{~mm}$ ), and the Haemulidae ( $\min 44 \mathrm{~mm}$, max $611 \mathrm{~mm}$, mean $193 \mathrm{~mm}$ ), most individuals are between 100 and $300 \mathrm{~mm}$ in length with many smaller individuals giving a slight skew towards the smaller size classes.

The Scaridae (min $42 \mathrm{~mm}$, max $944 \mathrm{~mm}$, mean 260 $\mathrm{mm}$ ) and Lutjanidae (min $23 \mathrm{~mm}$, max $981 \mathrm{~mm}$, mean $256 \mathrm{~mm}$ ) do not have a normal distribution, although they resemble normal curves with a few large individuals giving the curve a slight skew towards the larger size.

The Serranidae (min $35 \mathrm{~mm}$, max $1217 \mathrm{~mm}$, mean $350 \mathrm{~mm}$ ), Scombridae (min $63 \mathrm{~mm}$, $\max 3041 \mathrm{~mm}$, mean $551 \mathrm{~mm}$ ), and Carangidae (min $62 \mathrm{~mm}, \max 1412 \mathrm{~mm}$, mean $269 \mathrm{~mm}$ ) present bimodal distributions with two population sizes, each corresponding to different species living in different environments.

In order to establish a baseline for discussion of the fishing techniques and gear used by the Amerindian populations studied, a biometric reference has been developed (Froese and Pauly, 2018; http://specifyportal.flmnh.ufl.edu/fishes/), including TL at the juvenile phase, maturity, as well as the mean and maximum size during the adult phase (Table 5).

The Carangidae, Haemulidae, and Lutjanidae were harvested undersize at maturity, but none of the other families were fished under the mature size. However, the high diversity of species in these families requires caution regarding interpretation.

The mean fish sizes from all ecosystems decreased over time (Figure 6), especially from the Early Ceramic Age through the Late Ceramic Age and the Colonial period: Archaic $244.6 \mathrm{~mm}$, ECA $303.8 \mathrm{~mm}$, ECB $403.3 \mathrm{~mm}$, LCA $249.8 \mathrm{~mm}$, LCB $249.8 \mathrm{~mm}$, Colonial $203.3 \mathrm{~mm}$. This result supports the findings of previous research about decreasing coral fish size from the Early to Late Ceramic Age (Quitmyer, 2003; Wing and Wing, 2001, p. 3) and from the 17th to late 19th century AD (Quitmyer et al., 2013; Wallman and Grouard, 2017). This appears to be associated with human agency. Indeed, rising human populations and demand for food increased the pressure on marine ecosystems with long-term costs in terms of available biomass (Burgess et al., 2013; Jackson et al., 2001). However, the distributions are different through time: Bimodal distributions are clearly seen in the Archaic and Early Ceramic Age suggesting the simultaneous use of diverse fishing techniques in different environments, whereas the Late Ceramic Age and Colonial appeared as normal distributions with a few large individuals giving the curve a slight skew towards the larger sizes, suggesting a selection over the natural range of the smaller species. Thus, the subsistence economy was highly influenced by cultural and/or environmental choices.

\section{Techniques, Strategies, and Fishing Gears}

The main purpose of the development of this set of biometric parameters was to better interpret where species were caught (and how), according to their modes and 


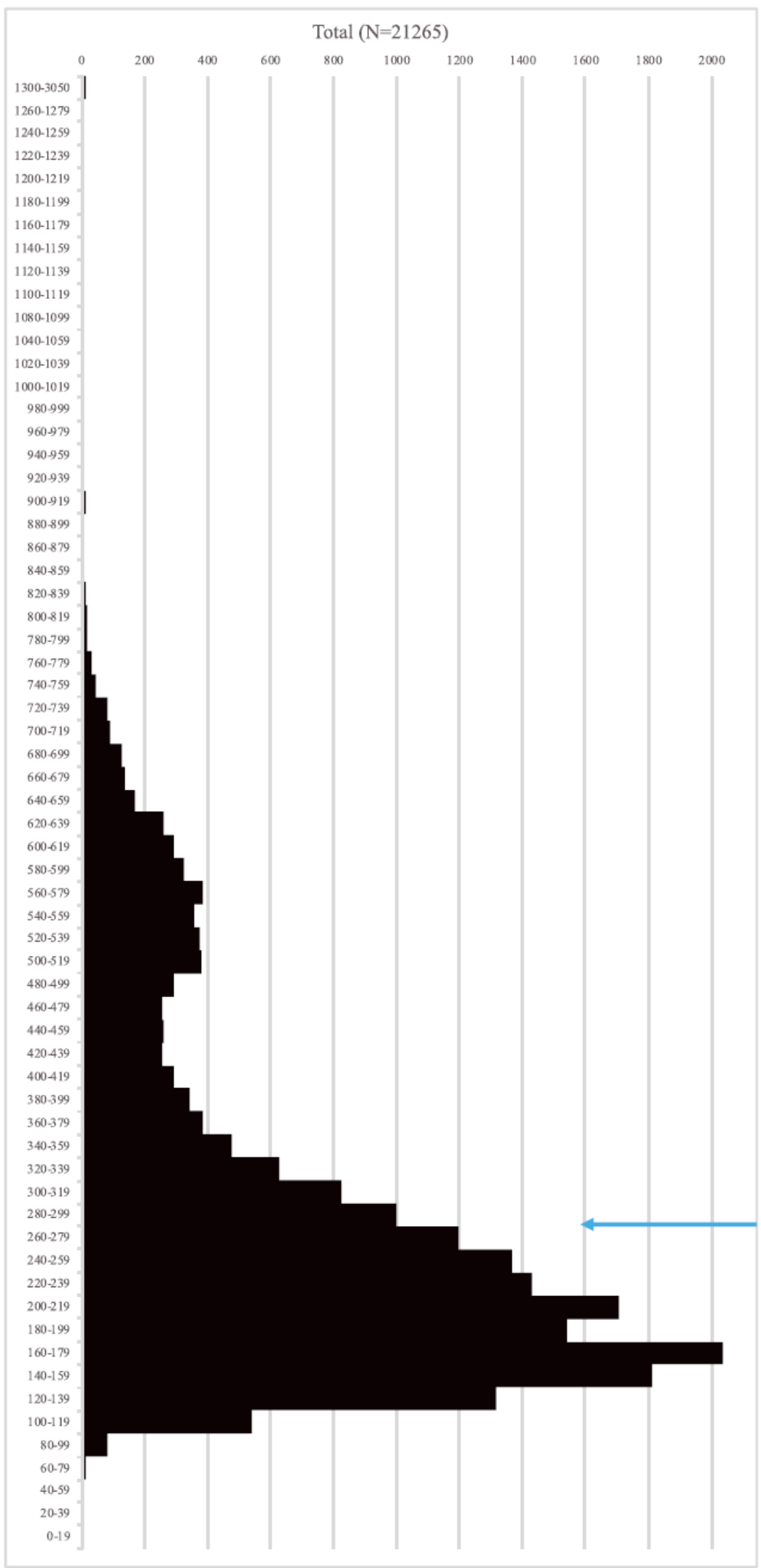

Figure 4. Fish size (standard length) for the height families during all periods $(n=21,265)$. The blue arrow symbolizes the mean $(293.1 \mathrm{~mm})$

[Color figure can be viewed at https:// onlinelibrary.wiley.com] 
Table 4. Basic statistics of the archaeological fish size estimations (standard length in $\mathrm{mm}$ )

$\begin{array}{lllll}\text { Family } & \text { N } & \text { Mean } & \text { Max } & \text { Min } \\ \quad \text { Holocentridae } & 176 & 188.9 & 403.1 & 89.0 \\ \text { Serranidae } & 1,740 & 350.2 & 1,1216.6 & 35.3 \\ \text { Carangidae } & 2,663 & 268.7 & 1,412.3 & 62.4 \\ \text { Lutjanidae } & 3,261 & 256.4 & 980.5 & 22.8 \\ \text { Haemulidae } & 3,742 & 193.4 & 610.9 & 43.7 \\ \text { Scaridae } & 3,983 & 259.7 & 943.7 & 41.9 \\ \text { Acanthuridae } & 2,184 & 161.2 & 455.8 & 59.9 \\ \text { Scombridae } & 3,516 & 550.6 & 3,041.1 & 63.1 \\ \text { Total } & 21,265 & 293.1 & 3,041.1 & 22.8 \\ \text { Period } & & & & \\ \text { Archaic } & 109 & 244.6 & 483.0 & 150.6 \\ \text { ECA } & 2,533 & 303.8 & 1,035.6 & 102.8 \\ \text { ECB } & 5,439 & 40.3 & 1,555.2 & 22.8 \\ \text { LCA } & 2,438 & 249.8 & 1,725.5 & 43.7 \\ \text { LCB } & 9,713 & 249.8 & 3,041.1 & 35.3 \\ \text { Colonial } & 1,033 & 203.3 & 943.7 & 59.9 \\ \text { Total } & 21,265 & 293.1 & 3,041.1 & 22.8\end{array}$

and place of life during their growth cycle, because we can observe specimens that are born in one ecosystem and mature in another (Nagelkerken et al., 2000). So, the elaboration of hypotheses about Amerindian fishery strategies have generally been based on the ethology of the species from bibliographical sources and from ethnographic and ethnohistorical data (Archambault, 1972; Aubin-Roy, 1968; Benoist, 1959; Blanchet et al., 2002; Bonniol, 1980; Bouchon et al., 2002; Carpenter, 2002; Froese and Pauly, 2018; Handler, 1970). The Amerindians from the Lesser Antilles are close in genetics, language, space, and time with the last Amerindians from North America. Consequently, the ethnohistorical data provide very strong inferences for interpreting palaeofisheries' techniques.
With respect to the sizes of the fish captured by these populations, our reconstruction work has revealed definite trends. The trends from our study are those revealed by the SL distribution curves. They have given us a glimpse of the possible anthropogenic selections that follow a normal, Poisson, or bimodal distribution (statistical test). Of course, some species or specimens' sizes are available in nature but not available for the fishery method at that time and are not present in the archaeological samples. As a result, the aggregation and dispersal elements have guided us in interpreting the fishing techniques used by these Amerindian peoples. Finally, from the fish size estimates and the consulted sources (archaeological, ethnohistorical, ethnographic, and biological), it was possible to infer various strategies and gear used by the Amerindian fishermen.

The zooarchaeological fishing techniques vary according to the targeted species, specimen size and age, and its environment (bottom cover, depth, distance from shore, and seasonality):

- The pelagic channel fish zooarchaeological populations (Figure 5) were large fishes, normally distributed, such as mackerels/tunas/ bonitos, and jacks with a bimodal distribution, which translates to several capture techniques: bow and arrow, harpoon, large nets, and longlines. The deployment of these various fishing technologies in such habitats suggests that pre-Columbian people would have most likely used watercraft.

- The rocky bottom zooarchaeological fish populations, the groupers, follow a normal distribution, but with several large individuals,

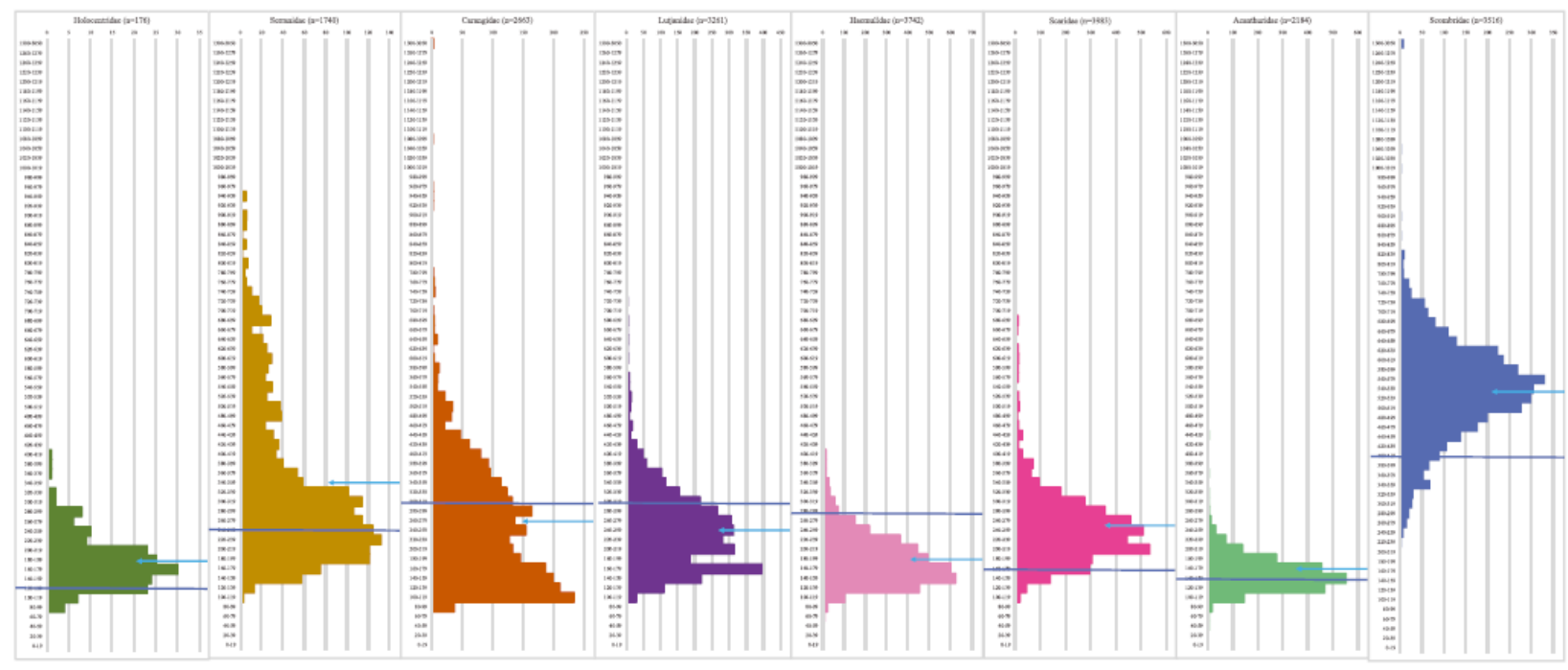

Figure 5. Fish size (standard length) of the Holocentridae $(n=176)$, Serranidae $(n=1,740)$, Carangidae $(n=2,663)$, Lutjanidae $(n=3,261)$, Haemulidae $(n=3,742)$, Scaridae $(n=3,983)$, Acanthuridae $(n=2,184)$, Scombridae $(n=3,516)$. The blue arrow symbolizes the mean and the line symbolizes the size at maturity (see Table 5) [Color figure can be viewed at https://onlinelibrary.wiley.com] 
Table 5. Biometric table of taxa studied in archaeoichthyological assemblages (data extracted from fishbase.org and flmnh.ufl.edu)

\begin{tabular}{|c|c|c|c|c|c|}
\hline Family & Species & $\begin{array}{l}\text { Juvenile phase } \\
\text { LT LS }(\mathrm{mm})\end{array}$ & $\begin{array}{l}\text { Maturity } \\
\text { LT/LS (mm) }\end{array}$ & $\begin{array}{l}\text { Adult phase } \\
\text { Mean LT/LS (mm) }\end{array}$ & $\begin{array}{l}\text { Maximum size } \\
\text { LT } \max (\mathrm{mm})\end{array}$ \\
\hline \multirow[t]{2}{*}{ Holocentridae } & Holocentrus adscencionis & $<135$ & 135 & 250 & 350 \\
\hline & Holocentrus rufus & $<145$ & 145 & 250 & 610 \\
\hline \multirow[t]{7}{*}{ Serranidae } & Cephalopholis cruentata & $<160$ & 160 & 200 & 426 \\
\hline & Epinephelus guttutus & $<250$ & 250 & 400 & 760 \\
\hline & Epinephelus itajara & $<1,280$ & 1,280 & 1,500 & 2,500 \\
\hline & Epinephelus adscendionis & $?$ & $?$ & 350 & 610 \\
\hline & Cephalopholis fulva & $<160$ & 160 & $?$ & 410 \\
\hline & Mycteroperca acutrirostris & $?$ & $?$ & ? & 800 \\
\hline & Mycteroperca tigris & $<460$ & 460 & 400 & 1,010 \\
\hline \multirow[t]{11}{*}{ Carangidae } & Seriola rivoliana & $?$ & $?$ & 900 & 1,600 \\
\hline & Caranx ruber & $<310$ & 310 & 500 & $590+690$ ठิ \\
\hline & Caranx latus & $<370$ & 370 & 600 & 1,010 \\
\hline & Carangoides bartholomaei & $<450$ & 450 & 500 & 1,000 \\
\hline & Trachinotus carolinus & $<250$ & 250 & 400 & 640 \\
\hline & Trachinotus goodei & $?$ & $?$ & 350 & 500 \\
\hline & Trachinotus falcatus & $<547$ & 547 & 1,220 & 486 ㅇ 547 ふ઼ \\
\hline & Seriola dumerili & $<1,090$ & 1,090 & 1,000 & 1,900 \\
\hline & Decapterus punctatus & $>110$ & 110 & 180 & 300 \\
\hline & Decapterus macarellus & $?$ & $?$ & 300 & 460 \\
\hline & Selar crumenophthalmus & $?$ & 170 & $?$ & 700 \\
\hline \multirow[t]{4}{*}{ Lutjanidae } & Lutjanus vivanus & $<500$ & 500 & 450 & 830 \\
\hline & Lutjanus apodus & $<250$ & 250 & 350 & 672 \\
\hline & Etelis oculatus & $?$ & $?$ & 640 & 1,000 \\
\hline & Lutjanus bucanella & $<310$ & 310 & 500 & 750 \\
\hline \multirow[t]{9}{*}{ Haemulidae } & Anisotremus surinamensis & $<200$ & 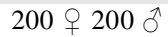 & 450 & 830 \\
\hline & Anisotremus virginicus & $<406$ & 406 ○ 500 ठ & 250 & 406 \\
\hline & Conodon nobilis & $<180$ & $180 \bigcirc 180$ ठ & 250 & 336 \\
\hline & Haemulon album & $<305$ & $305+500$ ठ & 500 & 790 \\
\hline & Haemulon aurolineatum & $<140 \bigcirc 180 \hat{\sigma}$ & 140 & 180 & 250 \\
\hline & Haemulon flavolineatum & $<160$ & $160 \bigcirc 170$ ఠ & 170 & 300 \\
\hline & Haemulon melanurum & $<190$ & $190 \bigcirc 200 \hat{\sigma}$ & 250 & 330 \\
\hline & Haemulon plumierii & $<167$ ㅇ $186 \hat{\jmath}$ & 190 & 300 & 530 \\
\hline & Haemulon sciurus & $<185 \bigcirc 250$ & $300 \bigcirc 350$ ○ & 250 & 460 \\
\hline \multirow[t]{3}{*}{ Scaridae } & Sparisoma viride & $<163$ & 163 & 380 & 640 \\
\hline & Sparisoma chrysopterum & $?$ & $?$ & 250 & 460 \\
\hline & Scarus coeruleus & $?$ & $?$ & 350 & 1,200 \\
\hline \multirow[t]{3}{*}{ Acanthuridae } & Acanthurus bahianus & $<150$ & 151 & 250 & 380 \\
\hline & Acanthurus chirurgus & $?$ & $?$ & 250 & 390 \\
\hline & Acanthurus coeruleus & ? & ? & 350 & 390 \\
\hline \multirow[t]{9}{*}{ Scombridae } & Thunnus albacares & $<1,033$ & 1,033 & $1,050 \mathrm{FL}$ & $2,930 \mathrm{FL}$ \\
\hline & Thunnus atlanticus & $?$ & $?$ & $720 \mathrm{FL}$ & $1,080 \mathrm{FL}$ \\
\hline & Auxis thazard & $<300$ & 300 & 600 & $650 \mathrm{FL}$ \\
\hline & Katsuwonus pelamis & $<400$ & 400 & $800 \mathrm{FL}$ & $110 \mathrm{FL}$ \\
\hline & Euthynus alletteratus & $<418$ & 418 & 800 & 1,220 \\
\hline & Scomberomorus brasiliensis & $<419$ & 419 & 650 & $1,250 \mathrm{FL}$ \\
\hline & Scomberomorus cavalla & $<500$ & 500 & $700 \mathrm{FL}$ & 1,840 \\
\hline & Scomberomorus maculatus & $<425$ & 425 & ? & $910 \mathrm{FL}$ \\
\hline & Scomberomorus regalis & $<405$ & 405 & $?$ & 1,830 \\
\hline
\end{tabular}

which probably hides a multimodal curve, reflecting the use of three or four capture techniques: Nets, traps, hook/line, and bow and arrow.

- The size classes of parrotfishes follow a natural distribution, called a Poisson law distribution, with many individuals of small sizes, which indicates the use of traps, seine nets, and fine mesh nets.
- The mangrove and sandy bottom fish zooarchaeological populations, such as the juveniles of grunts and snappers (Table 5), show a statistically Poisson law distribution that results from the nonselective nature of techniques that causes the mortality of fish of all ages, especially young individuals. For example, fish poison was widely used, as described by early Europ- 


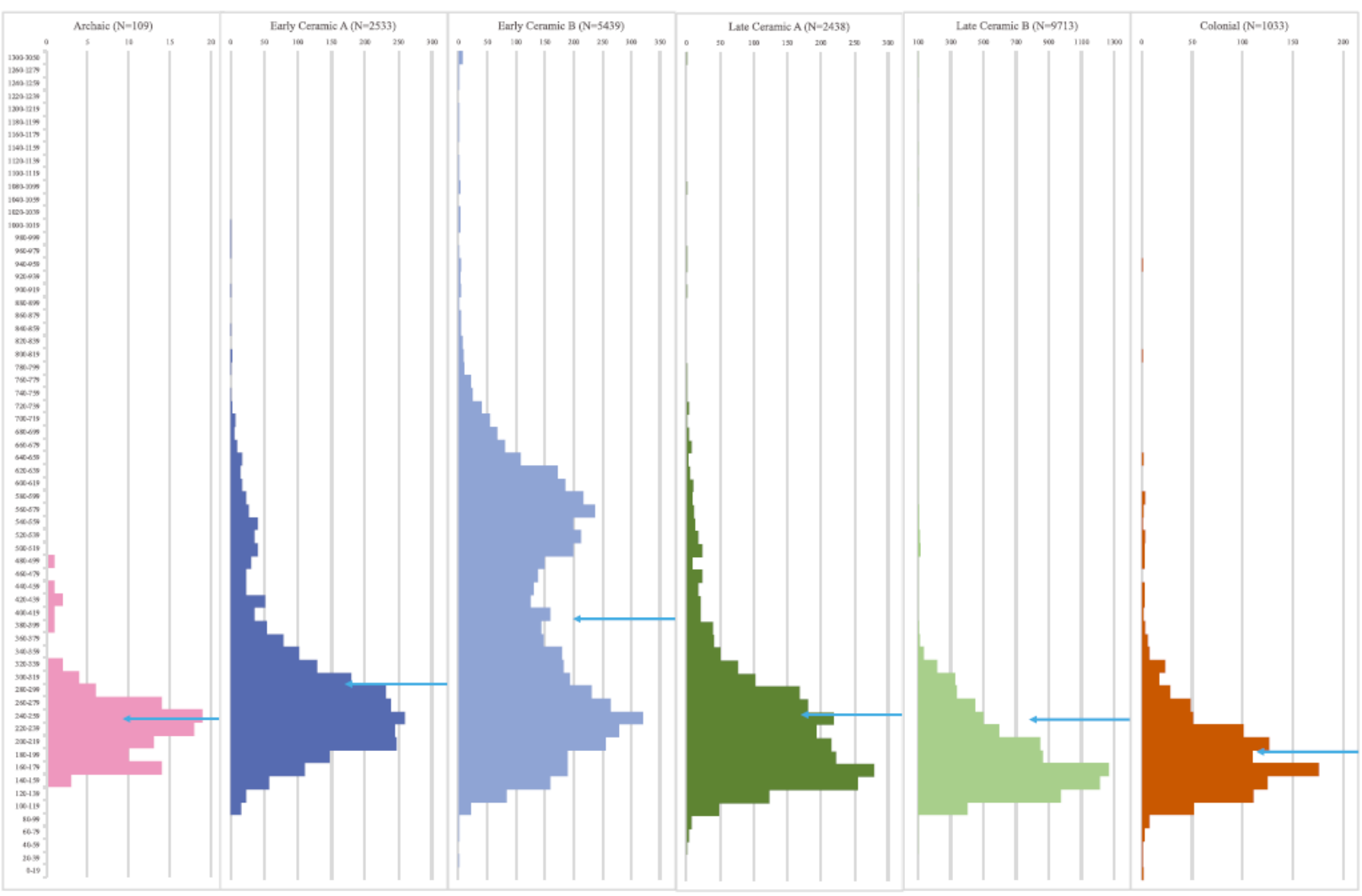

Figure 6. Size of the height fish families through time: Archaic $(n=109)$, Early Ceramic A $(n=2,533)$, Early Ceramic B $(n=5,439)$, Late Ceramic A $(n=2,438)$, Late Ceramic B $(n=9,713)$, Colonial $(n=1,033)$ [Color figure can be viewed at https://onlinelibrary.wiley.com]

ean chroniclers in the West Indies. The use of fish poisons is found cross-culturally and is widely practiced by modern Amazonian Amerindians, Barbuda fisher folk, and even fisheries biologists.

It is likely that these Amerindian societies were able to employ fishing strategies adapted to specific underwater environments, as is the case for the capture of fish from rocky habitats using longlines. The same is true for the development of traps placed on reefs or coral reefs to catch the fish specific to these ecosystems. Finally, if we look at migratory pelagic species that do not approach the coast (such as yellowfin tuna, Thunnus albacares, blackfin tuna, Thunnus atlanticus, and skipjack tuna, Katsuwonus pelamis), it is reasonable to think that the use of a boat was necessary for their capture. These fish appear along the Atlantic coast during the first months of the year, in very fast schools hunting off the continental slope. From AprilMay, they get closer to the coast to hunt around the coral reefs and bays of the Caribbean Sea. At the beginning of autumn these fish are less abundant and even seem to disappear from the coast (Sacchi et al., 1981).

Moreover, many coral reef fish exhibit habitat partitioning throughout their lifetimes as ontogenetic shifters: juveniles of Haemulidae, Labridae, Pomacentridae, Lutjanidae, and Scaridae schools grow in the mangroves and seagrass beds (during the dry season from April to June), but coral reefs are dominated by adult fish (Nagelkerken et al., 2000). Because fish size is highly correlated with age and growth maturity and hence their ecosystemic location, seasonality can be estimated (Grouard et al., 2017).

The fishing methods varied over time, as illustrated by the size curves (Figure 6): the bimodal curves (with angling and spearing) are more prevalent during the Early Ceramic Age, and they tend to give way to Poisson's law curves during Late Ceramic Age: the Amerindians refocused on smaller fish using nets and traps. So, the seasonality of the fisheries during the Early Ceramic Age is strongly marked by the presence of these pelagic fish. However, only a sclerochronological study will make it possible to discern the seasonality of the other species (Grouard et al., 2017).

\section{Conclusions}

One of the immediate objectives of this work was the reconstruction of fish sizes from archaeological fish remains recovered from Amerindian midden environments. Amerindian peoples thrived in the Lesser Antilles for 1,500 years before the arrival of European colonial forces. The colonial settlers of the Caribbean initially employed techniques and approaches to hunting, fishing, and gathering native to their homelands. As the waves of South American settlers became familiar with the possibilities and limitations of their new homelands, there was a culturally driven adaptation to these environments that 
resulted in the artisanal, traditional practices of Antillean subsistence fishing that survive today.

Our osteometric approach, focusing on the eight fish families most consumed by the Amerindian populations of the Lesser Antilles, has sought to bring a deeper understanding of the interrelationships between fishery culture, environmental parameters, and long-term exploitation profiles. Going beyond the species of fish caught, we looked at the sizes of fish to try and identify the techniques used by fishermen to capture these resources along with the environments exploited. Even when considering the limitations of the zooarchaeological fish remains due to taphonomic and sampling strategies, the wealth, breadth, and volume of the ichthyofauna from the assemblages studied is indeed a good representation of the Amerindian fishery as discussed through this osteometric work. In terms of the fishing technology applied in the various time periods, as noted by the anthropologist $\mathrm{J}$. Benoist (1959), lines, nets, and traps are the three main gear of Martinique fishermen. It is likely that the same triad of practices survived the passage of time and emerged to be among the most popular set of fishing techniques used by local fishermen. This gear was adapted towards the capture of desired species and would reflect good knowledge of the natural environment and the logic that governed the social relations of these groups, because, according to R. Cresswell (2003, p. 4), "the concept of techniques 'nested in the social' means that technical decisions are made for social reasons and vice versa."

Although there are no "perfect" models and all models are subject to the data and techniques available at the time of their construction, this work resulted from 6,000 measurements, and thus provides unique insights into aspects of the chaîne opératoire of the Amerindian fishery of the Lesser Antilles. Interaction between nature and culture placed unique markers in the landscape, seascape, and its resources but more importantly provided a cultural template for many of the Indigenous peoples that followed.

These activities, carried out individually or collectively, show a depth of knowledge about the local environment and all the species, migratory or not. It alludes to navigation techniques, the construction of boats, the making of tailor-made equipment for the targeted fish species and, in the terrestrial domain, the exploitation of plant species for the manufacture of fishing gear and boats.

This chaîne opératoire is a web of cognitive and practical tools necessary for the world of subsistence fishing. It includes multiples stages of acquisition and preparation (cooking, drying, smoking, etc.) and social signatures, such as indicators of the existence of collaborative networks of exchange between villages or islands. This approach provides a rather encouraging opportunity to expand this work to other species exploited in the region and extend this osteometric work to archaeoichthyological assemblages uncovered in the greater Caribbean region (Florida, Mexico, Nicaragua, Panama, Colombia, and Venezuela) and in the Brazilian island of Marajó. Whereas in the short term we will work on additional species and consider increasing the reference collections for Centropomidae, Labridae, Carangidae, and Scombridae, in the longer term, we will work towards building larger regional profiles of Amerindian fishing.

\section{Acknowledgements}

This research was founded by the ATM Biodiversité of MNHN and a postdoctoral grant from the Fyssen Foundation (SG). Special thanks go to Dr. Kitty Emery, Dr. Elisabeth Wing, and Sylvia Scudder from the Florida Museum of Natural History for their help in accessing the osteological specimens from the Florida Museum of Natural History collections. Thanks also to Karyne Debue and Stéphanie Bréhard for their valuable help in accessing the faunal collections from the UMR7209 AASPE. We want to deeply thank the anonymous reviewer and Dr. Orangel Aguilera for their comments that greatly improved the paper.

\section{Zooarchaeological Curation}

The zooarchaeological remains will be curated at Direction Régionale de l'Archéologie de la Guadeloupe, Direction Régionale de l'Archéologie de la Martinique, Barbuda Research Complex and MNHN-AASPE laboratory. The modern fish osteological collections will be curated at FLMNH, University of Nebraska-Lincoln and MNHN-AASPE laboratories. The details of the basic statistics of the formulas and equations are available from the corresponding author (Grouard) on request.

\section{Supporting Information}

Additional supporting information may be found online at https://onlinelibrary.wiley.com/journal/10991212.

\section{References}

Archambault, J. 1972. De la voile au moteur: Technologie et changement social aux Saintes. In J. Benoist (Ed.), L'archipel inachevé: Culture et société aux Antilles françaises (pp. 267292). Montréal, Quebec, Canada: Presses de l'Université de Montréal, Collection Recherches Caraïbes.

Aubin-Roy, J. 1968. Vieux-Fort (Guadeloupe). Techniques et coopération dans un village de pêcheurs. Montréal, Quebec, Canada: Département d'Anthropologie, Université de Montréal.

Bain, A., Faucher, A. M., Kennedy, L. M., LeBlanc, L. R., Bum, M. J., Boger, R., and Perdikaris, S. 2017. Landscape transformation during Ceramic Age and Colonial Occupations of Barbuda, West Indies. Environmental Archaeology, 23(1), 36-46. https://doi.org/10.1080/14614103.2017.1345115

Benoist, J. 1959. Individualisme et traditions techniques chez les pêcheurs martiniquais. Les Cahiers d'outre-Mer, XII, 265-285. https://doi.org/10.3406/caoum.1959.2127

Blanchet, G., Gobert, B., and Guérédrat, J.-A. 2002. La pêche aux Antilles Martinique et Guadeloupe. Paris, France: IRD éditions.

Bonniol, J.-L. 1980. Terre-de-Haut des Saintes. In Contraintes insulaires et particularisme ethnique dans la Caraïbe. Paris, France: Editions Caribéennes.

Bonnissent, D., Serrand, N., Bruxelles, L., Fouéré, P., Grouard, S., Sellier-Ségard, N., and Stouvenot, C. 2018. Island societies during the Archaic Age in the Lesser Antilles: The issue of resources in Saint-Martin. Chapter 15. In C. Hofman, and A. Antzcac (Eds.), New Insights into the Archaic of the CircumCaribbean. SAA 81st Annual Meeting, Orlando, Florida, USA: Tuscaloosa, Alabama, USA: Alabama Press.

Bouchon, C., Bouchon-Navarro, Y., and Louis, M. 2002. Les écosystèmes marins côtiers des Antilles. In G. Blanchet, B. Gobert, and J.-A. Guérédrat (Eds.), La pêche aux Antilles Martinique et Guadeloupe (pp. 21-43). Paris, France: IRD éditions. 
Brinkhuizen, D. C., and Clason, A. T. 1986. Fish and archaeology. In Study in osteometry, taphonomy, seasonality and fishing methods. Oxford, United Kingdom: British Archaeological Reports.

Burgess, M. G., Polasky, S., and Tilman, D. 2013. Predicting overfishing and extinction threats in multispecies fisheries. PNAS, 110(40), 15,943-11,594. doi: 10.1073/pnas. 1314472110

Carpenter, K. E. 2002. The living marine resources of the Western Central Atlantic Fishing Area 31 (FAO species identification sheets for fishery purposes) (p. 5). Rome, Italy: FAO Species Identification Guide for Fishery Purposes and American Society of Ichthyologists and Herpetologists Special Publication.

Casteel, R. W. 1974. On the number and sizes of animals in archaeological faunal assemblages. Archaeometry, 16, 238-243. doi: 10.1111/j.1475-4754.1974.tb00109.x

Casteel, R. W. 1976. Fish remains in archaeology and paleo-environmental studies. New York, New Yor, USA: Academic Press.

Chenorkian, R. 1996. Pratique archéologique statistique et graphique. Paris, France: Éditions Errance et Adam.

Clason, A. T., and Prummel, W. 1977. Collecting, sieving, and archaeozoological research. Journal of Archaeological Science, 4 , 171-175. doi: 10.1016/0305-4403(77)90064-4

Cooke, R., and Jiménez, M. 2004. Teasing out the species in diverse archaeofaunas: Is it worth the effort? An example from the tropical Eastern Pacific. Archaeofauna, 13,19-35.

Cresswell, R. (2003). Geste technique, fait social total. La technique est-il dans le social ou face à lui? Techniques \& Culture [En ligne] 40, online July 11, 2006, consulted Nov 2, 2018. doi: $10.4000 /$ tc. 1576

Desse, J., and Desse-Berset, N. 1996a. Archaeozoology of groupers (Epinephelinae). Identification, osteometry and keys to interpretation. Archaeofauna, 5, 121-127.

Desse, J., and Desse-Berset, N. 1996b. On the boundaries of osteometry applied to fish. Archaeofauna, 5, 171-179.

Desse, J., Desse-Berset, N., and Rocheteau, M. 1987. Contribution à l'ostéométrie du Mulet (Mugil capito, 1829). Juans-les-Pin, Antibes: APDCA

Desse, J., Desse-Berset, N., and Rocheteau, M. 1989. Les Profils Rachidiens Globaux. Reconstitution de la taille des poissons et appréciation du nombre minimal d'individus à partir des pièces rachidiennes. Revue de Paléobiologie, 8(1), 89-94.

Espindola Rodrigues, N., and Grouard, S. 2014. Reconstitution de la taille des poissons archéologiques et pratiques de pêche chez les Amérindiens précolombiens des Petites Antilles (500 av. J.C. à 1000 ap. J.-C.). Master Evolution Patrimoine Naturel et Sociétés, Spécialité Quaternaire, Préhistoire, Lignées humaines et Histoire des Sociétés, MNHN.

Froese, R., and Pauly, D. 2018. FishBase. World Wide Web electronic publication at www.fishbase.org, version 06/2018.

Giovas, C. M. 2016. Though she be but little: Resource resilience, Amerindian foraging, and long-term adaptive strategies in the Grenadines, West Indies. Journal of Island and Coastal Archaeology, 11(2), 1-26. doi: 10.1080/15564894.2016.1193572

Gould, S. J. 1966. Allometry and size in ontogeny and phylogeny. Biological Review of the Cambridge Philosophical Society, 41, 587-640. doi: 10.1111/j.1469-185X.1966.tb01624.x

Gould, S. J. 1971. Geometric similarity in allometric growth: A contribution to the problem of scaling in the evolution of size. American Naturalist, 105(942), 113-137. doi: 10.1086/282710

Grouard, S. 2001a. Subsistance, systèmes techniques et gestion territoriale en milieu insulaire antillais précolombien: Exploitation des Vertébrés et des Crustacés aux époques Saladoïdes et Troumassoïdes de Guadeloupe (400 av. J.-C. à 1500 ap. J.-C.). In Préhistoire: École Doctorale "Environnement et Archéologie." Paris, France: Université de Nanterre.

Grouard, S. 2001b. Faunal remains associated with Late Saladoid and Post-Saladoid occupations at Anse à la Gourde, Guadeloupe, French West-Indies: Preliminary results. Archaeofauna, 10, 71-98.
Grouard, S. 2010. Caribbean Archaeozoology. In G. M. Goñalons, J. Arroyo-Cabrales, and O. J. Polaco (Eds.), Current advances in Latin-American Archaeozoology, Xth ICAZ International Conference (pp. 89-109). México City, México: Instituto Nacional de Antropología e Historia y Consejo Nacional para la Ciencia y la Tecnología.

Grouard, S., Perdikaris, S., Bonnissent, D., and Espindola Rodrigues, N. 2017. Chronology of the Caribbean palaeofisheries. In G. Carenti, and B. Wilkens (Eds.), ICAZ FRWG 19-Fish and fishing communities. Understanding ancient and modern fisheries through archaeological fish remains (pp. 28-29). Alghero-Stintino, Italy: Associazione Culturale Tabularasa, University of Sassari.

Handler, J. S. 1970. Aspects of Amerindian ethnography in 17th century Barbados. Caribbean Studies, 9(4), 50-72.

Hofman, C. L., and Hoogland, M. L. P. 2004. Social dynamics and change in the Northern Lesser Antilles. In A. Delpuech, and C. L. Hofman (Eds.), Late Ceramic Age societies in the Eastern Caribbean. British Archaeological Reports International series 1273. (pp. 47-58). Oxford.

Huxley, J. S. 1932. Problems of relative growth. London, United Kingdom: Methuen.

Jackson, J. B. C., Kirby, M. X., Berger, W. H., Bjorndal, K. A., Botsford, L. W., Bourque, B. J., ... Warner, R. R. 2001. Historical overfishing and the recent collapse of coastal ecosystems. Science, 293, 629-638. doi: 10.1126/science.1059199

Jiménez-Cano, N. G., and Masson, M. A. 2016. Estimation of fish size from archaeological bones of hardhead catfishes (Ariopsis felis): Assessing pre-Hispanic fish acquisition of two Mayan sites. Journal of Archaeological Science, Reports, 8, 116-120. doi: 10.1016/j.jasrep.2016.05.063

Keegan, W. 2000. West Indian Archaeology. 3. Ceramic age. Journal of Anthropological Research, 8(2), 135-167.

Kimirei, I. A., Nagelkerken, I., Mgaya, Y. D., and Huijbers, C. M. 2013. The mangrove nursery paradigm revisited: Otolith stable isotopes support nursery-to-reef movements by Indo-Pacific fishes. PLoS One, 8(6), e66320. doi: 10.1371/journal.pone.0066320

Krebs, C. J. 1989. Ecological methodology. New York, New York, USA: Harper Collins Publishers.

Leach, B. F., and Boocock, A. 1993. Prehistoric fish catches in New Zealand. British Archaeological Reports, International Series 584. Oxford, United Kingdom.

Leach, B. F., and Boocock, A. 1995. The estimation of live fish catches from archaeological bone fragments of the New Zealand snapper Pagrus auratus. Records of the Museum of New Zealand, 3,1-28.

Leach, B. F., Davidson, J. M., Horwood, L. M., and Anderson, A. J. 1996a. The estimation of live fish size from archaeological cranial bones of the New Zealand barracouta Thyrsites atun. Records of the Museum of New Zealand, 6,1-25.

Leach, B. F., Davidson, J. M., Horwood, L. M., and Mallon, S. 1996b. The estimation of live fish size from archaeological cranial bones of the New Zealand kahawai Arripis trutta. Records of the Museum of New Zealand, 7, 1-20.

Lidour, K., Vorenger, J., and Béarez, P. 2018. Size and weight estimations of the spangled emperor (Teleostei: Lethrinidae: Lethrinus nebulosus) from bone measurements elucidate the fishing grounds exploited and ancient seasonality at Akab (United Arab Emirates). International Journal of Osteoarchaeology, 28, 681-694. doi: 10.1002/oa.2683

MacArthur, R. H., and Wilson, E. O. 1967. The theory of island biogeography. Monographs in population biology. Princeton, New Jersey, USA: Princeton University Press.

Mauss, M. 1923-1924. Essai sur le don. Forme et raison de l'échange dans les sociétés primitives, l'Année Sociologique, seconde série 1923-1924, re-edition. Paris, France: Sociologie et Anthropologie, PUF. 
Nagelkerken, I., Dorenbosch, M., Verberk, W. C. E. P., Cocheret de la Morinière, E., and van der Velde, G. 2000. Importance of shallow-water biotopes of a Caribbean bay for juvenile coral reef fishes: Patterns in biotope association, community structure and spatial distribution. Marine Ecology Progress Series, 202, 175-192. doi: 10.3354/meps202175

Page, L. M., Espinosa-Pérez, H., Findley, L. T., Gilbert, C. R., Lea R. N., Mandrak, N. E., ... Nelson, J. S. 2013. Common and scientific names of fishes from the United States, Canada, and Mexico (7th ed., Vol. 34). Bethesda, Maryland, USA: American Fisheries Society, Special Publication.

Pauly, D. 1995. Anecdotes and the shifting baseline syndrome of fisheries. Tree, 10, 430.

Pauly, D., Christensen, V., Dalsgaard, J., Froese, R., and Torres, Jr., F., 1998. Fishing down marine food webs. Science, 279, 860863. doi: 10.1126 /science. 279.5352 .860

Payne, S. 1975. Partial recovery and sample bias. In A. T. Clason (Ed.), Archaeozoological studies (pp. 7-17). New York, New York, USA: American Elsevier.

Perdikaris, S. 1999. From chiefly provisioning to commercial fishery: Long-term economic change in arctic Norway. World Archaeology, 30, 388-402. doi: 10.1080/00438243.1999.9980419

Perdikaris, S., Bain, A., Boger, R., Grouard, S., Faucher, A. M., Rousseau, V., ... Medina-Triana, J. 2017. Cultural heritage under threat: The effects of climate change on the small island of Barbuda, Lesser Antilles. In T. Dawson, C. Nimura, E. Lopez-Romero, and M.-Y. Daire (Eds.), Public archaeology and climate change (pp. 138-148). Oxford, United Kingdom: Oxbow Books. doi: 10.2307/j.ctvh1dp4n.19

Peters, R. H. 1983. The ecological implications of body size. Cambridge, United Kingdom: Cambridge University Press. doi: 10.1017/CBO97805 11608551

Pointier, J. P., and Lamy, D. 1998. Guide des coquillages des Antilles. Abymes, Guadeloupe: PLB Editions.

Quitmyer, I. R. 2003. Zooarchaeology of Cinnamon Bay St. John US Virgin Islands: Pre-Columbian over-exploitation of animal resources. Bulletin of the Florida Museum of Natural History, 44(1), 131-158.

Quitmyer, I. R. 2004. What kind of data are in the back dirt? An experiment on the influence of screen size on optimal data recovery. Archaeofauna, 13, 109-129.

Quitmyer, I. R., Atkins, S. C., and Bowen, J. 2013. The zooarchaeology of the middle 17th and late 18th centuries, King's Castle, Bermuda: The cost of living in paradise. Bermuda Journal of Archaeology and Maritime History, 20, 114-141.
Quitmyer, I. R., Wing, E. S., Hale, H. S., and Jones, D. S. 1985. Volume 2: Zooarchaeology. In W. H. Adams (Ed.), Aboriginal subsistence and settlement archaeology of Kings Bay Locality, Reports of Investigations 2. Gainesville, Florida, USA: University of Florida, Department of Anthropology.

Reitz, E. J., and Cordier, D. 1983. Use of allometry in zooarchaeological analysis. In J. Clutton-Brock, and C. Grigson (Eds.), Animals and Archaeology 2: Shell middens, fishes, and birds. British Archaeological Reports International Series 183. (pp. 237252). Oxford, United Kingdom.

Reitz, E. J., Quitmyer, I. R., Hale, H. S., Scudder, S. J., and Wing, E. S. 1987. Application of allometry to zooarchaeology. American Antiquity, 52(2), 304-317. doi: 10.2307/281782

Reitz, E. J., and Wing, E. S. 1999. Zooarchaeology. Cambridge, United Kingdom: Cambridge University Press.

Rousseau, Y. 2010. Structure des peuplements ichtyologiques des récifs coralliens de la Martinique en relation avec la qualité de l'habitat. Thèse doctorale de l'École Pratique des Hautes Études. Cybium, 34(3), 1-302.

Sacchi, J., Lagin, A., Chaudemar, V., and Langlais, C. 1981. La pêche des espèces pélagiques aux Antilles françaises. État actuel et perspective de développement. Science et Pêche, Bull. Inst. Pêches Marit., 312, 1-15.

Schmidt-Nielsen, K. 1984. Scaling: Why is animal size so important? Cambridge, United Kingdom: Cambridge University Press. doi: 10.1017/ CBO9781139167826

Serrand, N. 2007. L'économie des sociétés précolombiennes des Petites Antilles. Contribution des données sur l'exploitation des invertébrés marins et terrestres. In Les Nouvelles de l'Archéologie (Vol. 108-109) (pp. 78-90). Archéologie des départements français d'Amérique.

Wallman, D., and Grouard, S. 2017. Enslaved laborer and sharecropper fishing practices in 18th-19th Century Martinique: A zooarchaeological and ethnohistorical study. Journal of Ethnobiology, 37(3), 398-421. doi: 10.2993/0278-0771-37.3.398

Wheeler, A., and Jones, A. K. G. 1989. Fishes. Cambridge, United Kingdom: Cambridge University Press.

Wing, E., and Wing, S. R. 1995 Prehistoric ceramic age adaptation to varying diversity of animal resources along the West Indian archipelago. Journal of Ethnobiology, 15(1), 119148.

Wing, S. R., and Wing, E. S. 2001. Prehistoric fisheries in the Caribbean. Coral Reefs, 20, 1-8. 